\title{
Systematic Review-The Potential Implications of Different Platelet-Rich Plasma (PRP) Concentrations in Regenerative Medicine for Tissue Repair
}

\author{
Pietro Gentile $1,2, *$ (I) and Simone Garcovich ${ }^{3}$ \\ 1 Surgical Science Department, Plastic and Reconstructive Surgery, “Tor Vergata" University, 00133 Rome, Italy \\ 2 Scientific Director of AIRMESS, Academy of International Regenerative Medicine \& Surgery Societies, \\ 1201 Geneva, Switzerland \\ 3 Institute of Dermatology, F. Policlinico Gemelli IRCSS, Università Cattolica del Sacro Cuore, \\ 00168 Rome, Italy; simgarko@yahoo.it \\ * Correspondence: pietrogentile2004@libero.it; Tel.: +39-33-8851-5479
}

Received: 20 July 2020; Accepted: 7 August 2020; Published: 9 August 2020

\begin{abstract}
The number of studies evaluating platelet-rich plasma (PRP) concentration has substantially grown in the last fifteen years. A systematic review on this field has been realized by evaluating in the identified studies the in vitro PRP concentration-also analyzing the platelet amount-and the in vivo PRP effects in tissue regeneration compared to any control. The protocol has been developed in agreement with the Preferred Reporting for Items for Systematic Reviews and Meta-Analyses-Protocols (PRISMA-P) guidelines. Multistep research of the PubMed, MEDLINE, Embase, PreMEDLINE, Ebase, CINAHL, PsycINFO, Clinicaltrials.gov, Scopus database and Cochrane databases has permitted to identify articles on different concentrations of PRP in vitro and related in vivo impact for tissue repair. Of the 965 articles initially identified, 30 articles focusing on PRP concentration have been selected and, consequently, only 15 articles have been analyzed. In total, $40 \%(n=6)$ of the studies were related to the fixed PRP Concentration Group used a fixed PRP concentration and altered the platelet concentration by adding the different volumes of the PRP (lysate) to the culture. This technique led to a substantial decrease in nutrition available at higher concentrations. Sixty percent $(n=9)$ of the studies were related to the fixed PRP Volume Group that used a fixed PRP-to-media ratio ( $\mathrm{Vol} / \mathrm{Vol})$ throughout the experiment and altered the concentration within the PRP volume. For both groups, when the volume of medium (nutrition) decreases, a lower rate of cell proliferation is observed. A PRP concentration of $1.0 \times 10^{6} \mathrm{plt} / \mu \mathrm{L}$, appears to be optimal thanks to the constant and plentiful capillary nutrition supply and rapid diffusion of growth factors that happen in vivo and it also respects the blood decree-law. The $\mathrm{PRP} /$ media ratio should provide a sufficient nutrition supply to prevent cellular starvation, that is, $\mathrm{PRP} \leq 10 \%(\mathrm{Vol} / \mathrm{Vol})$ and thus best mimic the conditions in vivo.
\end{abstract}

Keywords: PRP concentration; PRP tissue regeneration; PRP regenerative medicine; PRP in vivo effect

\section{Introduction}

The number of studies evaluating platelet-rich plasma (PRP) concentration has substantially increased during the last fifteen years (2005-2020). PRP is a concentrate of platelets and growth factors (GFs) obtained by the centrifugation of venous blood. It may be autologous or allogenic and generally, it is possible to distinguish the autologous PRP in two different products-Autologous activated PRP (AA-PRP) and autologous not-activated PRP (A-PRP). These products are considered routine for plastic surgeons and dermatologists with consolidated experience in regenerative medicine [1,2]. Preparation methods are not standardized yet and regenerative mechanisms related to the biomolecular pathway are still the object of study. The in vivo/in vitro effects of AA-PRP and A-PRP in different field of 
regenerative medicine to improve the tissue repair have been reported [1-3]. In particular, in the last fifteen-years, the PRP application has expanded to a wide range of clinical fields, including plastic surgery [4], trichology [5-7], dermatology [8,9], maxillofacial surgery [10], orthopedics [11] and others.

The biomolecular rationale for the PRP's application is represented by the regenerative properties of the platelets favoring the wound healing. Platelets hold about 50-80 alpha-granules that contain hundreds of bioactive proteins, including a wide range of GFs principally represented by platelet-derived growth factor (PDGF), fibroblast growth factor (FGF), vascular endothelial growth factor (VEGF), epidermal growth factor (EGF), transforming growth factor-beta 1 (TGF- $\beta 1$ ), insulin-like growth factor (IGF), connecting tissue growth factor (CTGF) and hepatocyte growth factor (HGF) [12,13]. Every one of these major GFs is involved in a specific biomolecular function during tissue repair playing a fundamental role in wound healing and also in hair re-growth. In fact, when secreted, the GFs binding to the transmembrane receptors of the targeted area cells, producing cell growth, mitogenesis, chemotaxis, promoting the proliferation and extracellular matrix (ECM) formation and thus tissue repair [12,13].

Additionally, the A-PRP's and AA-PRP's anti-apoptotic effects have been described as the most important factors stimulating hair re-growth through the Bcl-2 protein activation (anti-apoptotic regulator) and Akt signaling, improving the dermal papilla cells survival (DPCs) during the hair cycle [2].

Currently, several kit and procedures are described, to prepare PRP.

These procedures are different on the basis of the centrifugation's time and g-force or revolutions used (revolutions per minute -RPM-), the platelet's amount obtained, the GF type and amount and chemokine release. These differences are increased by wide biological and temporal variation [11]. Consequently, it seems to be very difficult to select which methods, kits and procedures for PRP are better [14] or which are more or less adequate for treating different types of tissue damages displaying different platelet counts and different PRP concentrations.

However, the positive impact and efficacy of PRP in tissue repair appear to be confirmed by the many studies published but a standardized procedure that aims to obtain the same platelet count in different PRP products has not yet been established. Additionally, different PRP concentrations added to the cell culture may produce different effects in terms of cellular proliferation and differentiation.

In the present systematic literature review, the effectiveness of different platelet concentrations for cell proliferation focusing on in vitro studies was evaluated, discussing the most effective PRP concentration in vivo.

\section{Methods}

\subsection{Regulatory Framework on Clinical PRP Use}

The human autologous PRP is considered a blood component for not-transfusional use. These blood components must be distinguished in two different categories-a) for infiltrative/topical use, (not considered cells therapy) b) for cellular therapy, which involves complex techniques of bioprocessing of therapeutic cells. In this last case, reference is made to Regulation n.1394/2007 of the European Parliament (EC) and by the reflection paper on the characterization of cutting edge treatment medicinal products draft concurred, 20 June 2014 European Medicines Agency (EMA)/Committee for Advanced therapies (CAT)/600280/2010 Rev 1, while for infiltrative/topical use the European references are represented by Decrees of November 9, 2007, n. 207 and n. 208 and each nation provide a national law.

Currently, in Italy, the PRP procedure must be performed following the dispositions reported in the "Blood Law-Decree, 2 November 2015" represented by several parameters that must be respected and obtained during PRP preparation as following displayed:

- $1 \times 10^{6} \mu \mathrm{L} \pm 20 \%$ final platelet amount;

- Topical and/or infiltrative use exclusively; 
- Quality and sterility checks on the sample obtained;

- Not over $55 \mathrm{~mL}$ of blood to withdraw for every patient;

- $\quad$ Labeling of every PRP sample;

- Specific Informed consent;

- Side events module;

- Data processing module;

- Patients screening on the basis of exclusion criteria (platelet disorders, thrombocytopenia, anti-aggregating therapy, bone marrow aplasia, uncompensated diabetes, sepsis and cancer).

PRP preparation methods must be conducted in accordance with the European Laws and Institutional Guidelines and they must be performed following the principles outlined in the Declaration of Helsinki and internationally consented ethics in clinical research [15], performing a quality assessment based on the Strengthening the Reporting of Observational Studies in Epidemiology (STROBE) checklist [16] and respecting the national laws representing in Italy by "Blood Law-Decree, 2 November 2015."

For all physicians that want to start with the PRP applications in the regenerative medicine field, the authors suggest strictly respecting the guidelines highlighted in the Italian Blood Law-decree, as it was reported to follow all the Good Clinical Practices (GCPs).

This article has been realized on the basis of a research contract (R. D. \#1467/2017) between the first author P.G. and the University of Rome "Tor Vergata," Italy.

\subsection{Search Strategy}

This systematic review was registered in International prospective register of systematic reviews (PROSPERO, https://www.crd.york.ac.uk/prospero/\#myprospero) with ID code number: CRD42020196804.

Due to the growing interest in regenerative medicine via autologous biotechnologies, a number of studies have been conducted to assess the in vitro concentration of A-PRP and AA-PRP and related in vivo impact in tissue repair. A systematic review protocol was developed in accordance with the Preferred Reporting for Items for Systematic Reviews and Meta-Analyses-Protocols (PRISMA-P) guidelines. The search was conducted in accordance with the PRISMA guidelines and the Cochrane handbook. A multistep search of the PubMed, MEDLINE, Embase, PreMEDLINE, Ebase, CINAHL, PsycINFO, Clinicaltrials.gov, Scopus and Cochrane databases was performed to identify studies on different concentrations of PRP in vitro and related effects in vivo for tissue regeneration. Tissue regeneration with PRP searching without a language or publishing-time restriction has been performed. 965 articles (539 articles found in PubMed and 426 in EMBASE) using the keyword "PRP concentrations," "Platelet concentrations in PRP products," "PRP concentration and tissue regeneration," "PRP implication in stem cell proliferation," "PRP implication in stem cell differentiation" were identified.

Of the 965 articles initially identified, 30 articles focusing on PRP concentration were selected and, consequently, only 15 articles were analyzed.

\subsubsection{Study Assessment}

The objective of the present systematic review was to assess the selected articles comparing the in vitro different PRP concentrations' effects in stem cell proliferation and differentiation with the in vivo related impact on tissue regeneration. Additional objectives were to evaluate the impact of the different platelets and GFs concentration, in soft and bone tissue repair.

Investigations included in this article had to match predetermined criteria according to the PICOS (patients, intervention, comparator, outcomes and study design) approach. Criteria for inclusion and exclusion are specified as following-P-Patients (inclusion criteria-age 18-80 years, males and females who suffered from soft tissue defects, bone tissue defects, scars, outcomes of scars, burns, 
outcomes of burns, hemifacial atrophy, aging, ulcers, diabetic foot, lower extremity ulcers, chronic ulcers, skin disease, knee disease, cartilage disease, craniomaxillofacial disease, hair loss; and exclusion criteria-patient with platelets disorders, thrombocytopenia, anti-aggregating therapy, bone marrow aplasia, uncompensated diabetes, sepsis, cancer. No ethnicity restrictions were placed on the population of the study; I-Intervention (inclusion criteria-local and/or topical application of autologous PRP, autologous PRP infiltration, allogeneic PRP use, PRP in vitro analysis, PRP in vivo analysis.; exclusion criteria-sonicated PRP, pre-clinical investigations, animal studies related to not human transplants.); C-Comparator (inclusion criteria-any type of control, internal, external and different product; exclusion criteria-not provided); O-Outcomes (inclusion criteria-wound healing, soft tissue repair, bone tissue repair, cartilage repair; exclusion criteria—not applied); S-Study design (inclusion criteria-randomized clinical studies, randomized placebo-controlled trials/randomized, double-blind, placebo- and active-controlled, half-head trial/double-blind, placebo-controlled pilot trial/blinded, reviews, systematic review and metanalyses; exclusion criteria-case report, expert opinion, letter to editor, pre-clinical model (animal studies), experimental studies, investigations reporting PRP combined with biomaterials, articles identified as bias (not correct match with the key word used, group of study $<10$ patients. No limitations were provided regarding the PRP method of preparation.

This systemic review, performed with the PICOS approach, in which only randomized placebo-controlled trials/randomized, double-blind, placebo- and active-controlled, half-head study/double-blind, placebo-controlled pilot study/blinded, randomized clinical trials, review, systematic review and metanalyses focused on PRP concentration in tissue regeneration were analyzed, is considered an EBM 1a level study according the Oxford Centre for Evidence-Based Medicine (OCEBM), March 2009 (https://www.cebm.net/2009/06/oxford-centre-evidence-based-medicine-levelsevidence-march-2009/).

\subsubsection{Study Selection}

In total, 965 records were identified and selected using Prisma Flow [17] (www.prisma-statement. org) (Scheme 1)—426 studies in EMBASE OvidSP, 539 in PubMed. The 160 duplicates in the two bases were excluded; the initial number of studies was 525 .

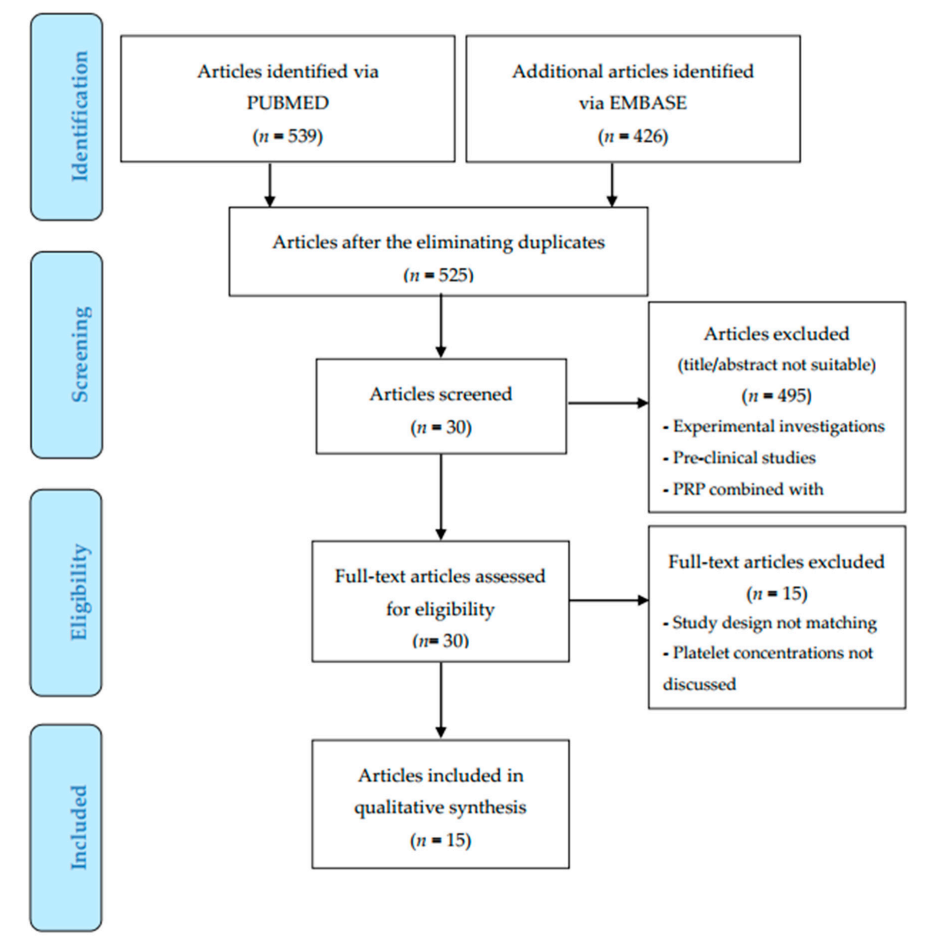

Scheme 1. Preferred Reporting for Items for Systematic Reviews and Meta-Analyses (PRISMA) flow diagram. 
After the first screening (title and abstract), 495 studies were excluded, frequently due to the use of animal cells, no focus on different PRP concentration or because the design combined PRP with different types of biomaterials. Additional records were identified in the references.

The remaining 30 papers were included for full-text screening, of which 15 papers were included for the final analysis.

\subsubsection{Data Extraction}

Data were independently gathered by the first investigator (PG) and checked by the last investigator (SG), only from the retrieved articles. Any disagreement on the gathered data has been settled by a consensus between SG and PG. No attempt has been made to obtain specific or missing data from the investigators. The following data have been extracted—study design, patient number, first author, year of publication, type of procedure and primary and secondary results.

The quality of the included articles has been independently assessed by the first and the last investigators (PG and SG) using the Cochrane Collaboration's Risk of Bias Assessment tool for RCT15 while using the Newcastle-Ottawa Scale to evaluate the individual non-randomized studies [18].

\subsubsection{Result Measures}

The primary result has been the in vitro effect of different PRP concentrations in stem cell proliferation and differentiation (culture, microscopical and histological evaluation were analyzed). Secondary results were in vivo evaluation of PRP application/infiltration/topical use in tissue repair. The in vivo analysis was performed considering results of laboratory test, magnetic resonance imaging (MRI) and/or Computed Tomography (CT) of soft/bone tissue treated and biopsy. Objective evaluation (performed by the investigators and supported by instrumental analysis), subjective evaluation (performed by the patients treated on the basis of the healing, aesthetic and functional outcomes), a photographic and functional assessments were considered.

All results gathered from the articles have been reported with the same measurements retrieved from the papers. Advanced dressing, adipose-derived mesenchymal stem cells (AD-MSCs), Stromal Vascular fraction cells (SVFs) and autologous regenerative therapies have been used as a control in some of the included papers, while in other studies, patients were respectively allocated into study groups when they underwent PRP and to the control group when they underwent the placebo or other treatments. Missing data have been dealt with according to previously validated estimations $[19,20]$.

\section{Results}

\subsection{The In Vitro Impact of Platelet-Rich Plasma}

In general, all the studies consistently report that PRP may increase cell proliferation in vitro. An exception is skin fibroblasts in the study of Anitua et al. [21]. Different studies assayed different extracellular substances and gene expression and thus difficult to compare systematically. Still, three studies observed an increased synthesis of collagen type I and/or II or hyaluronic acid (HA) [21-23]. Four studies observed increased cell motility and invasion at moderate [24-26] or relatively high concentration [27].

This systematic review detected two main types of groups:

- $\quad$ The Fixed PRP Concentration Group:

In a percentage of $40 \%(n=6)$ of the studies analyzed, a fixed initial PRP concentration was used. Different concentrations were achieved by varying the PRP-to-media ratio $(\mathrm{Vol} / \mathrm{Vol})$ in which the cells were cultured. Mishra et al. [28] and Wang et al. [29] had a similar initial PRP concentration (1.0 and $1.55 \times 10^{6} \mathrm{plt} / \mu \mathrm{L}$, respectively). They found an increase in proliferation up to $10 \% \mathrm{PRP}$ and a decrease when a volume of $20 \%$ PRP was used [28,29]. Hsu et al. [30] and Tavassoli-Hojjati et al. [31] used an initial PRP concentration of 1.124 and $1.194 \times 10^{6}$, respectively and observed a maximal proliferation 
at $5 \%$ PRP. However, in these studies, a volume of $10 \%$ was not a part of the coarse test scale and when the next concentration was tested (15\% and 50\% PRP), the proliferation rate declined [30,31]. Amable et al. also observed an increase in cell proliferation up to 10\% PRP and a decline when higher volume concentrations were used. The fixed PRP concentration was $2.94 \pm 1.9 \times 10^{6} \mathrm{plt} / \mu \mathrm{L}$ [32]. Giusti et al. [24] seem to belong to this group but do not clarify the PRP/media ratio $(\mathrm{Vol} / \mathrm{Vol})$ and thus it is difficult to compare to the others. It is difficult to compare the studies in an accurate metric manner due to the different initial PRP concentrations and different PRP volume concentrations tested. However, the data of this group loosely indicate that $10 \%$ of PRP $(\mathrm{Vol} / \mathrm{Vol})$ at a platelet concentration of $1-1.5 \times 10^{6}$ is the most effective in vitro. In general, the technique of this group leads to a substantial decrease in nutrition available at higher concentrations-when the PRP concentration (volume) increases, the culture medium (nutrition) will decrease.

\section{- The Fixed PRP Volume Group:}

Sixty percent of the studies $(n=9)$ utilized a fixed ratio of PRP to culture media $(\mathrm{Vol} / \mathrm{Vol})$ throughout the experiment, for example, $10 \% / 90 \%$ or $20 \% / 80 \%$. Different concentrations were achieved by diluting the original PRP-lysate within the chosen volume of PRP, frequently in Dulbecco's Modified Eagle Medium (DMEM) or $\alpha$-MEM. Haynesworth et al. [33], Jo et al. [22] and Wang et al. [29] used a ratio of $10 \% \mathrm{PRP}(\mathrm{Vol} / \mathrm{Vol})$ and observed an optimal proliferation rate at $1.6 \times 10^{6}, 4.0 \times 10^{6}$ (fibroblast) and $1.5 \times 10^{6} \mathrm{plt} / \mu \mathrm{L}$, respectively. Similar results found by Rughetti et al. [27]. Anitua et al. [21] and Berger et al. [26], on the other hand, used a PRP volume of $20 \%$ and found maximum proliferation rate at $0.767 \pm 0.95$ and 0.875 (young group) $\times 10^{6} \mathrm{plt} / \mu \mathrm{L}$, respectively- about half of Haynesworth et al. [33] and Wang et al. [29]. Graziani et al. [25] used the highest PRP/media ratio (33\%/67\%) and observed maximum proliferation of approx. $0.570 \times 10^{6}$ (osteoblast) and $0.228 \times 10^{6}$ (fibroblast) plt $/ \mu \mathrm{L}$. Unfortunately, Rughetti et al. [27] and Sadoghi et al. [34] did not clarify the exact ratio, which prevents a full comparison in the group. Sadoghi et al. [34] found the optimal platelet concentration to be five-fold and if we assume an average baseline in whole blood (WB) of $0.25 \times 10^{6} \mathrm{plt} / \mu \mathrm{L}$, the maximum proliferation can be estimated to be $1.25 \times 10^{6} \mathrm{plt} / \mu \mathrm{L}$ [34]. When Haynesworth et al. [33] increased the PRP-to-media ratio to $20 \% / 80 \%(\mathrm{Vol} / \mathrm{Vol})$ to obtain a platelet concentration of 10 -fold $\left(3.2 \times 10^{6} \mathrm{plt} / \mu \mathrm{L}\right)$, they observed a decrease in the proliferation rate.

One trait that emerges in this group is that studies using a fixed volume of PRP higher than $10 \%$ $(\mathrm{Vol} / \mathrm{Vol})$ observed lower optimal platelet concentration for proliferation. Still, Mazzocca et al. [35] differs from this trait and found that relatively moderate platelet concentrations as most effective, even if a PRP/media ratio of $10 \% / 90 \%$ was used.

All the data analyzed has been showed in Table 1.

\subsubsection{Platelet-Rich Plasma Impact Modulated by Cell Type}

This systematic review indicates that the effect of PRP varies according to cell type. According to Mishra et al. [28], Human Mesenchymal Stem Cells (HMSC) were more responsive to PRP than fibroblasts. Within the frame of the same experimental design, Graziani et al. [25] observed that the osteoblast was more receptive to a higher PRP concentration than fibroblasts. According to Jo et al. [36], the maximal proliferation rate for fibroblasts and HMSC was $4 \times 10^{6}$ and $8 \times 10^{6}$, respectively. The cell site origin might also be a factor. Anitua et al. [21] showed that fibroblasts from the skin did respond equally to PRP and Platelet poor Plasma (PPP), while PRP significantly stimulated the proliferation of fibroblasts from synovium and tendon in a dose-dependent manner. Regarding tendonal fibroblasts, earlier studies also report that tendons from different sites have different tissue structures, composition, cell phenotypes and metabolic characteristics $[37,38]$. Further research is needed to elucidate how different PRP concentrations affect different types of cells and how the same type of cells harvested from different sites respond. 
Table 1. Synthetic analysis of the outcomes: platelet-rich plasma (PRP) concentration (plt/ $\mu \mathrm{L})$ and PRP Volume $(\mathrm{Vol} / \mathrm{Vol})$.

\begin{tabular}{|c|c|c|c|c|c|c|c|}
\hline Investigators & $\begin{array}{c}\text { PRP Concentration } \\
\text { Evaluated (plt } / \mu L \text { or Fold } \\
\text { or WB) }\end{array}$ & $\begin{array}{l}\text { Optimal PRP } \\
\text { Concentration } \\
\text { Cell Proliferation } \\
\text { (Vol/Vol and } \\
\mathrm{plt} / \mu \mathrm{L} \text { or Fold })\end{array}$ & $\begin{array}{l}\text { Optimal PRP } \\
\text { Concentration } \\
\text { Cell Motility and } \\
\text { Invasion (plt } / \mu \mathrm{L})\end{array}$ & $\begin{array}{l}\text { Cells Type } \\
\text { Evaluated }\end{array}$ & $\begin{array}{c}\text { Fixed PRP } \\
\text { Concentration } \\
\text { Proliferation } /(\mathrm{plt} / \mu \mathrm{L})\end{array}$ & $\begin{array}{l}\text { Optimal } \\
\text { PRP/Media Ratio } \\
\text { (Vol/Vol) for Cell } \\
\text { Proliferation }\end{array}$ & Procedure \\
\hline $\begin{array}{l}\text { Wang et al. (2019) } \\
\text { [29] }\end{array}$ & $\begin{array}{c}\text { Platelet lysate } \\
\text { corresponding to } \\
0.2 \times 10^{6}, 0.5 \times 10^{6}, 0.8 \times \\
10^{6}, 1.0 \times 10^{6}, 1.2 \times 10^{6} \\
1.5 \times 10^{6}, 2.0 \times 10^{6} \\
2.7 \times 10^{6} \text { and } 3.0 \times 10^{6}\end{array}$ & $\begin{array}{c}10 \% \text { of } \\
1.5-3.0 \times 10^{6}\end{array}$ & Not tested & $\begin{array}{l}\text { HMSCs (bone } \\
\text { marrow) }\end{array}$ & $1.55 \times 10^{6}$ & $10 \%$ & $\begin{array}{c}1.25,1.5 \text { and } 1.9 \times 10^{6} \text { (mean } \\
\left.1.55 \times 10^{6}\right) \text { has been added to the } \\
\text { culture at a ratio of } 1 \%, 5 \% \text { and } 10 \% \\
\text { to media }(\mathrm{Vol} / \mathrm{Vol})\end{array}$ \\
\hline Hsu et al. (2009) [30] & $\begin{array}{c}1.124 \times 10^{6} \mathrm{plt} / \mu \mathrm{L} \text { has } \\
\text { been added to the wells in } \\
\text { concentration of } 2 \%, 5 \% \text {, } \\
15 \% \text {, and } 30 \%\end{array}$ & $\begin{array}{l}5 \% \text { of } 1.124 \times 10^{6} \\
\text { of } 5 \%(\mathrm{Vol} / \mathrm{Vol})\end{array}$ & Not evaluated & $\begin{array}{l}\text { Fibroblast, } \\
\text { Osteoblast }\end{array}$ & $1.124 \times 10^{6}$ & $5 \%$ & $\begin{array}{l}\text { PRP of } 1.124 \times 10^{6} \mathrm{plt} / \mu \mathrm{L} \text { has been } \\
\text { added to the wells in concentration } \\
\text { of } 2 \%, 5 \%, 15 \% \text { and } 30 \%\end{array}$ \\
\hline $\begin{array}{c}\text { Mishra et al. (2009) } \\
\text { [28] }\end{array}$ & $\begin{array}{c}1 \times 10^{6} \mathrm{plt} / \mu \mathrm{L} \\
\text { (not-activated) has been } \\
\text { added to the media at } \\
\text { ratio of } 1 \%, 5 \%, 10 \% \text { and } \\
20 \%(\mathrm{Vol} / \mathrm{Vol})\end{array}$ & $10 \%$ of $1 \times 10^{6}$ & Not evaluated & Fibroblast, HMSCs & $1 \times 10^{6}$ & $10 \%$ & $\begin{array}{c}\text { A standardized PRP containing } \\
1 \times 10^{6} \mathrm{plt} / \mu \mathrm{L} \text { has been added to } \\
\text { the culture at a ratio of } 0.1 \%, 1 \% \text {, } \\
5 \%, 10 \% \text { and } 20 \%(\mathrm{Vol} / \mathrm{Vol})\end{array}$ \\
\hline $\begin{array}{l}\text { Chen et al. (2012) } \\
\text { [39] }\end{array}$ & $\begin{array}{c}\text { Lysate from PRP of } \\
\text { 1. } \times 10^{6} \text { has been added } \\
\text { to the media at ratio of } 0 \% \text {, } \\
1 \%, 5 \%, 10 \%, \text { lysate } \\
(\mathrm{Vol} / \mathrm{Vol})\end{array}$ & $5 \%$ of $1 \times 10^{6}$ & Not evaluated & $\begin{array}{l}\text { Dental Pulp Stem } \\
\text { Cells }\end{array}$ & 1. $\times 10^{6} \mathrm{plt} / \mu \mathrm{L}$ & $5 \%$ & $\begin{array}{l}\text { PRP of } 1 . \times 10^{6} \mathrm{plt} / \mu \mathrm{L} \text { has been } \\
\text { added to the media }(\alpha-\mathrm{MEM}) \text { at } \\
\text { ratio of } 0 \%, 1 \%, 5 \%, 10 \%,(\mathrm{Vol} / \mathrm{Vol})\end{array}$ \\
\hline $\begin{array}{l}\text { Tavassoli-Hojjati et al. } \\
\text { (2016) [31] }\end{array}$ & $\begin{array}{l}1.194 \times 10^{6} \mathrm{plt} / \mu \mathrm{L} \text { diluted } \\
\text { in DMEM resulting in } \\
\text { concentration of } 0.1 \%, 5 \% \\
\text { and } 50 \%\end{array}$ & $5 \%$ of $1.194 \times 10^{6}$ & Not evaluated & Fibroblast & $1.194 \times 10^{6}$ & $5 \%$ & $\begin{array}{l}\text { Initial PRP contained an average of } \\
1.194 .000 \mathrm{plt} / \mu \mathrm{L}\end{array}$ \\
\hline $\begin{array}{l}\text { Giusti et al. (2014) } \\
\text { [24] }\end{array}$ & $\begin{array}{l}0.5 \times 10^{6}, 1 \times 10^{6}, 2 \times 10^{6} \\
3 \times 10^{6} \text { and } 5 \times 10^{6} \mathrm{plt} / \mu \mathrm{L}\end{array}$ & $\begin{array}{c}0.5 \times 10^{6} \\
(\mathrm{PRP} / \text { media ratio } \\
\text { unclear) }\end{array}$ & $\begin{array}{l}0.5 \times 10^{6}, \text { at } 46 \mathrm{~h} \\
(\mathrm{PRP} / \text { media ratio } \\
\quad \text { unclear })\end{array}$ & Tenocyte & $4.5 \times 10^{6}$ to $6 \times 10^{6}$ & Not displayed & $\begin{array}{l}\text { Initial PRP contained } 4.5 \times 10^{6} \text { to } \\
6 \times 10^{6} \mathrm{plt} / \mu \mathrm{L} \text {. The cells have been } \\
\text { treated with PRP-lysate which was } \\
\text { diluted in culture medium }+1 \% \\
\text { FDS to obtain } 0.5 \times 10^{6}, 1 \times 10^{6} \\
2 \times 10^{6}, 3 \times 10^{6} \text { and } 5 \times 10^{6} \mathrm{plt} / \mu \mathrm{L}\end{array}$ \\
\hline
\end{tabular}


Table 1. Cont

\begin{tabular}{|c|c|c|c|c|c|c|c|}
\hline Investigators & $\begin{array}{c}\text { PRP Concentration } \\
\text { Evaluated (plt } / \mu L \text { or Fold } \\
\text { or WB) }\end{array}$ & $\begin{array}{l}\text { Optimal PRP } \\
\text { Concentration } \\
\text { Cell Proliferation } \\
\text { (Vol/Vol and } \\
\text { plt } / \mu \mathrm{L} \text { or Fold })\end{array}$ & $\begin{array}{l}\text { Optimal PRP } \\
\text { Concentration } \\
\text { Cell Motility and } \\
\text { Invasion }(p 1 t / \mu \mathrm{L})\end{array}$ & $\begin{array}{l}\text { Cells Type } \\
\text { Evaluated }\end{array}$ & $\begin{array}{c}\text { Fixed PRP } \\
\text { Concentration } \\
\text { Proliferation } /(\text { plt } / \mu \mathrm{L})\end{array}$ & $\begin{array}{c}\text { Optimal } \\
\text { PRP/Media Ratio } \\
\text { (Vol/Vol) for Cell } \\
\text { Proliferation }\end{array}$ & Procedure \\
\hline $\begin{array}{l}\text { Amable et al. } \\
\text { (2014) [32] }\end{array}$ & $\begin{array}{c}2.94+/-1.9 \times 10^{6} \mathrm{plt} / \mu \mathrm{L} \\
\text { has been mixed with } \\
\text { culture media }(\alpha-\mathrm{MEM}) \text { to } \\
\text { obtain the following PRP } \\
\text { concentration: } 1 \%, 2.5 \% \text {, } \\
5 \%, 10 \%, 20 \%, 30 \%, 40 \% \\
\text { and } 50 \%(\mathrm{Vol} / \mathrm{Vol})\end{array}$ & $\begin{array}{c}10 \% \text { of } 2.94+/- \\
1.9 \times 10^{6}\end{array}$ & Not evaluated & $\begin{array}{l}\text { HMSC (bone } \\
\text { marrow, adipose } \\
\quad \text { tissue and } \\
\text { Wharton's Jelly) }\end{array}$ & $2.94+/-1.9 \times 10^{6}$ & $10 \%$ & $\begin{array}{c}\text { PRP of } 2.94+/-1.9 \times 10^{6} \mathrm{plt} / \mu \mathrm{L} \text { has } \\
\text { been mixed with culture media } \\
\text { ( } \alpha \text {-MEM) to obtain the following } \\
\text { PRP concentration: } 1 \%, 2.5 \%, 5 \% \text {, } \\
10 \%, 20 \%, 30 \%, 40 \% \text { and } 50 \% \\
(\text { Vol/Vol })\end{array}$ \\
\hline $\begin{array}{l}\text { Haynesworth et al. } \\
\text { (2002) [33] }\end{array}$ & $\begin{array}{l}\text { 0.625-fold, } 1.25 \text {-fold, } \\
2.5 \text {-fold and 5-fold }\end{array}$ & $\begin{array}{l}10 \% \text { of } 1.6 \times 10^{6} \\
\text { (5-folds over } \\
\text { baseline) }\end{array}$ & Not evaluated & HMSCs, Fibroblast & $1.6 \times 10^{6}$ & $10 \%$ & $\begin{array}{l}\text { The initial PRP contained } 1.6 \times 10^{3} \\
\text { plt/ } \mu \mathrm{L} \text { (5-fold). PRP-lysates } \\
\text { corresponding to PRP } \\
\text { concentrations of } 0.625,1.25 \text { and } 2.5 \\
\text { has been made by diluting the } \\
\text { lysate in DMEM. Each } \\
\text { concentration has been added to } \\
\text { the media in a ratio of } 10 \% / 90 \% \\
(\mathrm{Vol} / \mathrm{Vol})\end{array}$ \\
\hline $\begin{array}{l}\text { Graziani et al. } \\
\text { (2006) [25] }\end{array}$ & $\begin{array}{l}\text { 2.5-fold, 3.5-fold and } \\
4.2-5.5 \text {-fold (PRP Max) }\end{array}$ & $\begin{array}{l}33.3 \% \text { of } 2.5 \approx \\
0.570 \times 10^{6}\end{array}$ & $\begin{array}{c}33.3 \% \text { of } 2.5 \times \mathrm{Ca} \\
0.570 \times 10^{6}\end{array}$ & $\begin{array}{l}\text { Osteoblast, } \\
\text { Fibroblast }\end{array}$ & $\begin{array}{l}2.5 \times 0.570 \times 10^{6} \\
\quad(\text { Osteoblast }) \\
1 \times 0.228 \times 10^{6} \\
\quad(\text { Fibroblast })\end{array}$ & $33 \%$ & $\begin{array}{c}\text { Initial PRP contained } \\
\text { 800.000-1.370.000 plt/ } / \mu \mathrm{L} \text {. } \\
\text { Maximum PRP-lysate (PRP-Max) } \\
\text { has been diluted in DMEM to } \\
\text { obtain PRP-lysate containing } 250 \% \\
\text { 350\% over WB baseline }\end{array}$ \\
\hline $\begin{array}{l}\text { Rughetti et al. } \\
\text { (2008) [27] }\end{array}$ & $\begin{array}{c}0.3 \times 10^{6}, 0.5 \times 10^{6}, \\
0.75 \times 10^{6}, 1.25 \times 10^{6}, \\
1.75 \times 10^{6}, 2.25 \times 10^{6}, \\
2.75 \times 10^{6}, 3.25 \times 10^{6}, \\
4 \times 10^{6}, 5 \times 10^{6} \text { and } 7 \times 10^{6}\end{array}$ & $1.25 \times 10^{6}$ & $1.5 \times 10^{6}$ & Endothelial cell & $1.25 \times 10^{6}$ & Not displayed & $\begin{array}{l}\text { Initial PRP has been activated and } \\
\text { diluted in DMEM }+2.5 \% \text { FCS } \\
\text { (proliferation) or in DMEM only } \\
\text { (motility and invasion). Platelet } \\
\text { concentration at } 3 \times 10^{5}, 5 \times 10^{5} \\
7.5 \times 10^{5}, 1.25 \times 10^{6}, 1.75 \times 10^{6}, \\
2.25 \times 10^{6}, 2.75 \times 10^{6}, 3.25 \times 10^{6} \\
4 \times 10^{6}, 5 \times 10^{6} \text { and } 7 \times 10^{6} \mathrm{plt} / \mu \mathrm{L} \\
\text { has been added to the medium }\end{array}$ \\
\hline
\end{tabular}


Table 1. Cont

\begin{tabular}{|c|c|c|c|c|c|c|c|}
\hline Investigators & $\begin{array}{c}\text { PRP Concentration } \\
\text { Evaluated (plt } / \mu L \text { or Fold } \\
\text { or WB) }\end{array}$ & $\begin{array}{l}\text { Optimal PRP } \\
\text { Concentration } \\
\text { Cell Proliferation } \\
\text { (Vol/Vol and } \\
\text { plt } / \mu \mathrm{L} \text { or Fold) }\end{array}$ & $\begin{array}{l}\text { Optimal PRP } \\
\text { Concentration } \\
\text { Cell Motility and } \\
\text { Invasion }(p 1 t / \mu \mathrm{L})\end{array}$ & $\begin{array}{l}\text { Cells Type } \\
\text { Evaluated }\end{array}$ & $\begin{array}{c}\text { Fixed PRP } \\
\text { Concentration } \\
\text { Proliferation } /(\text { plt } / \mu \mathrm{L})\end{array}$ & $\begin{array}{l}\text { Optimal } \\
\text { PRP/Media Ratio } \\
\text { (Vol/Vol) for Cell } \\
\text { Proliferation }\end{array}$ & Procedure \\
\hline $\begin{array}{c}\text { Anitua et al. (2009) } \\
\text { [21] }\end{array}$ & $\begin{array}{c}0.16+/-1 \times 10^{6}, 0.404+/- \\
39 \times 10^{6}, 0.767+/-95 \times 10^{6} \\
\mathrm{plt} / \mu \mathrm{L}(2 \times \text { and } 4 \times \text { of } \\
\text { baseline })\end{array}$ & $\begin{array}{l}20 \% \text { of } 0.767+/- \\
95 \times 10^{6} \text { and } 0.404 \\
\quad+/-39 \times 10^{6}\end{array}$ & Not evaluated & Fibroblast & $0.767+/-95 \times 10^{6}$ & $20 \%$ & $\begin{array}{l}200 \% \text { and } 400 \% \text { of WB baseline. } \\
\text { Platelet concentration of } 404+/- \\
39 \times 10^{3} \text { and } 767+/-95 \times 10^{3} \\
\text { added to media in a } 20 \% / 80 \% \text { ratio }\end{array}$ \\
\hline $\begin{array}{c}\text { Mazzocca, (2012) } \\
{[35]}\end{array}$ & $\begin{array}{l}\mathrm{PRP}_{\mathrm{LP}}: 382.0+/- \\
111.6 \times 10^{3} \mathrm{plt} / \mu \mathrm{L}: \\
\mathrm{PRP}_{\mathrm{DS}}: 472.6+/- \\
224.2 \times 10^{3} \mathrm{plt} / \mu \mathrm{L} ; \\
\mathrm{PRP}_{\mathrm{HP}}: 940.1+/- \\
425.8 \times 10^{3} \mathrm{plt} / \mu \mathrm{L}\end{array}$ & $\begin{array}{c}10 \% \text { of } \mathrm{PRP}_{\mathrm{LP}}: \\
382.0+/- \\
111.6 \times 10^{3} \mathrm{plt} / \mu \mathrm{L} ; \\
10 \% \text { of } \mathrm{PRP}_{\mathrm{DS}}: \\
472.6+- \\
224.2 \times 10^{3} \mathrm{plt} / \mu \mathrm{L} ; \\
\text { No significance } \\
\text { between } \mathrm{PRP} \mathrm{LP}_{\mathrm{LP}} \\
\mathrm{PRP}_{\mathrm{DS}} \text { and } \mathrm{PRP} \mathrm{HP}_{\mathrm{HP}}\end{array}$ & Not evaluated & $\begin{array}{l}\text { Myocytes, } \\
\text { Osteoblast, } \\
\text { Tenocyte }\end{array}$ & $\begin{array}{c}382.0+/-111.6 \times 10^{3} \\
\left(\mathrm{PRP}_{\mathrm{LP}}\right)-\text { Myocytes } \\
472.6+/-224.2 \times 10^{3} \\
\left(\mathrm{PRP}_{\mathrm{DS}}\right)-\text { Osteoblast; } \\
382.0+/-111.6 \times 10^{3} \\
\left(\mathrm{PRP}_{\mathrm{LP}}\right) \text {-Tenocytes }\end{array}$ & $10 \%$ & $\begin{array}{l}\mathrm{PRP}_{\mathrm{LP}}: 382.0+/-111.6 \times 10^{3} \mathrm{plt} / \mu \mathrm{L}: \\
\text { PRP }_{\mathrm{DS}}: 472.6+/-224.2 \times 10^{3} \mathrm{plt} / \mu \mathrm{L} \\
\text { PRP }_{\mathrm{HP}}: 940.1+/-425.8 \times 10^{3} \mathrm{plt} / \mu \mathrm{L}\end{array}$ \\
\hline $\begin{array}{l}\text { Wang et al. (2011) } \\
\text { [23] }\end{array}$ & $\begin{array}{l}1.2-1.9 \times 10^{6} / \mu \mathrm{L}, 1 \%, 5 \% \\
\text { and } 10 \%(\mathrm{Vol} / \mathrm{Vol})\end{array}$ & $\begin{array}{c}10 \% \text { of } \\
1.5 \times 1.9 \times 10^{6}(4 \times)\end{array}$ & Not evaluated & Tenocyte & $1.55 \times 10^{6}$ & $10 \%$ & $\begin{array}{c}1.25,1.5 \text { and } 1.9 \times 10^{6} \text { (mean } \\
\left.1.55 \times 10^{6}\right) \text { has been added to the } \\
\text { culture at a ratio of, } 1 \%, 5 \% \text { and } \\
10 \% \text { to media }(\mathrm{Vol} / \mathrm{Vol})\end{array}$ \\
\hline $\begin{array}{l}\text { Sadoghi et al. } \\
\text { (2013) [34] }\end{array}$ & $\begin{array}{l}\text { 1-, 5- and } 10 \text { fold PRP has } \\
\text { been obtained by diluting } \\
\text { initial PRP in PPP. The } \\
\text { PRP/media ratio is unclear }\end{array}$ & 5 -fold $\approx 1.25 \times 10^{6}$ & Not evaluated & Fibroblast & 5 -fold & Not evaluated & $\begin{array}{l}\text { 1-, } 5 \text { - and } 10 \text { fold PRP has been } \\
\text { obtained by diluting initial PRP in } \\
\text { PPP. The PRP/media ratio is unclear }\end{array}$ \\
\hline $\begin{array}{c}\text { Berger et al. (2019) } \\
\text { [26] }\end{array}$ & $\begin{array}{c}\text { Platelet lysate } \\
\text { corresponding to platelet } \\
\text { levels of } 14 \times, 7 \times, 3.5 \times \\
1.75 \times \text { and } 0.9 \times \text { of } W B\end{array}$ & $\begin{array}{l}20 \% \text { of } 0.875 \times 10^{6} \\
\text { (Young group); } \\
20 \% \text { of } 3.5 \times 10^{6} \\
\text { (Old group) }\end{array}$ & $\begin{array}{l}\text { Old group: } \\
3.5 \times 10^{6}\end{array}$ & Fibroblast & $\begin{array}{l}\text { Young group: } \\
0.875 \times 10^{6} \\
\text { Old group: } 3.5 \times 10^{6}\end{array}$ & $20 \%$ & $\begin{array}{l}\text { Platelet lysate (PL) has been diluted } \\
\text { in PPP to obtain lysates } \\
\text { corresponding to platelet levels of } \\
14 \times, 7 \times, 3.5 \times, 1.75 \times \text { and } 0.9 \times \text { of } W B\end{array}$ \\
\hline
\end{tabular}




\subsubsection{PRP-to-Culture-Media Ratio: A Potential Bias}

The authors hypothesize that the main course of this difference is due to variations in the PRP-toculture-media ratio $(\mathrm{Vol} / \mathrm{Vol})$. As seen in The Fixed PRP Concentration Group, the highest PRP concentrations implied significantly lower nutrition levels in the culture wells because of the diluting technique. This point is seen in Hsu et al. [30], Amable et al. [32] and is particularly obvious in the study of Tavassoli-Hojjati et al. [31]. In the latter case, PRP (not lysate) corresponding to a platelet concentration of $1,194,000 / \mu \mathrm{L}$ was mixed with DMEM to process PRP concentrations of $0.1 \%, 5 \%$ and $50 \%$ in which the cells were cultured. The optimal concentration of $5 \%$ contained $45 \%$ more nutrition than the PRP of 50\%. A comparable pattern is seen in Giusti et al. [24], who initially produced a PRP that contained $4.5 \times 10^{6}$ to $6 \times 10^{6} \mathrm{plt} / \mu \mathrm{L}$. To make different concentrations of PRP-lysate, the initial PRP-lysate was diluted in DMEM + 1\% Fetal Bovine Serum (FBS). Then, starved cells were exposed to (i.e., cultured in) the different PRP concentrations. Although a statistical assessment is not possible, the optimal PRP-lysate of $0.5 \times 10^{6} \mathrm{plt} / \mu \mathrm{L}$ had significantly more nutrition than the highest concentration $\left(5 \times 10^{6} \mathrm{plt} / \mu \mathrm{L}\right)[24]$.

The comparable finding is revealed in The Fixed PRP Volume Group. The studies that advocate moderate platelet concentrations as most effective in inducing cell proliferation tended to have a higher fixed volume of PRP and, thus, a lower volume of culture media throughout the experiment. Graziani et al. [25] used $100 \mu \mathrm{L}$ media and $50 \mu \mathrm{L}$ PRP of any concentrations, which means a PRP part of 33.3\% ( Vol/ $\mathrm{Vol})$. The PRP-lysate containing $2.5 \times$ and $3.5 \times$ was diluted in extra DMEM to obtain the appropriate concentration. The highest concentration-PRP-max (4.2-5.5 $\times)$-received no extra DMEM. The cell cultures treated with lower platelet concentrations $(2.5 \times$ and $3.5 \times)$ received substantially more nutrition than the group of PRP-max. This point is also seen in Anitua et al. [21] and Berger et al. [26], who kept the PRP-to-media ratio constant at $20 \%$ over $80 \%$ and observed a platelet concentration of $0.767 \pm 0.95$ and 0.875 (young group) $\times 10^{6} \mathrm{plt} / \mu \mathrm{L}$ as most effective-approximately half of what is described in Haynesworth et al. [33], Rughetti et al. [27] and Sadoghi et al. [34]. Compared to Haynesworth et al. [33], Jo et al. [36] and Wang et al. [29] who utilized a 10/90 ratio ( Vol/Vol), Graziani et al. [25] and Anitua et al. [21] used about 23\% and 10\% less nutrition, respectively.

\subsubsection{Platelet-Rich Plasma Concentration Analysis}

PRP volume over 10\% might be critical in vitro. We have already seen that optimal platelet concentration in both Graziani et al. [25] and Anitua et al. [21] was significantly lower than in those who utilized a PRP concentration of 10\% ( Vol/ $\mathrm{Vol})$. Mishra et al. [28] diluted PRP-lysates of 1 million $\mathrm{plt} / \mu \mathrm{L}$ to MDEM at concentrations of $0.1 \%, 1 \% 5 \%, 10 \%$ and $20 \%(\mathrm{Vol} / \mathrm{Vol})$ and observed the highest cell proliferation in the 10\% PRP media. When 20\% of PRP was used, they observed a significant decline in proliferation in the fibroblast culture. Comparable results were seen in Amable et al. and Haynesworth et al. when 20\% PRP was used [32,33] and Hsu et al. when the PRP concentration was increased from $5 \%$ to $15 \%$ [30]. However, Chen et al. deviates from this prominent tendency and observed maximal proliferation when 5\%, not 10\%, PRP was applied to culturing dental pulp stem cells [39]. These findings are of importance, taking into consideration the dramatic increase in nutrition requirement that happens when a cell undergoes growth and proliferation compared to its quiescent state [40]. A large quantity of nucleotides, amino acids and lipids are required when a cell goes from the S0 state into the anabolic phases and proliferates into two viable daughter cells [41]. Therefore, there is reason to speculate that the PRP-to-media ratio in the studies that advocated a low or moderate platelet concentration resulted in a lack of cellular nutrition and possible starvation.

\subsubsection{Cell Density Per Well}

The cell density per well (volume) may also be a bias factor, since an initial higher number of cells will require more nutrition for a prolonged proliferation and viability. Amable et al. [32] and Tavassoli-Hojjati et al. [31] utilized a 24-wells plate in their tests but seeded $1 \times 10^{3}$ and 
$50 \times 10^{3}$ cells/well, respectively. This may partly explain that the optimal platelet concentration according to Amable et al. [32] is 5-6 times higher than that according to Tavasolli-Hojjati et al. [31] $\left(10 \%\right.$ of $2.9 \pm 1.9 \times 10^{6} \mathrm{plt} / \mu \mathrm{L}$ versus $5 \%$ of $1.194 \times 10^{6} \mathrm{plt} / \mu \mathrm{L}$, respectively). With the exception of Amable et al. [32] and Graziani et al. [25], the included studies give no exact information about the cell density per well. In general, information about the type of culture plate (most often "96-wells plate") and the number of cells/well or cells $/ \mathrm{cm}^{2}$ is provided. However, the working volume inside each well is stretchable and allows for nutrition variation in each experiment. Therefore, the studies do not allow statistical analysis of this issue.

\subsection{In Vivo Impact of Platelet-Rich Plasma}

In vitro studies should always be utilized with care. However, since the studies reviewed above aimed to point out or suggest an ideal platelet concentration in PRP treatment, the optimal platelet concentration in vivo should be discussed. According to Vander Heiden et al. [41], the cells in multicellular organisms, including mammals, are normally exposed to a constant flow of nutrition supply. When PRP is injected in a tissue site and GFs are released, the arterial and capillary system will provide a constant flow of nutrition. The in vivo situation is, therefore, markedly different from the in vitro condition in which the nutrition supply is fixed and limited. In vivo, the GFs will also gradually be diffused and transported out of the target area relatively quickly, which leads to a decline in levels of GFs within hours, even if the molecular weight of the GFs is high (6-150 kDa) [42]. Based on these perspectives, the high concentration group seems to best mimic the conditions in vivo due to the low PRP-to-culture-media (nutrition) ratio. Still, extremely high platelet concentrations could be inadequate in injection sites where capillary density is low. Dernek et al. [43] tested the effect of PRP clinically on knee osteoarthritis at 1 million plt/ $\mu \mathrm{L}$ (group 1 ) and 3 million plt $/ \mu \mathrm{L}$ (group 2). Regarding Western Ontario and McMaster University's Osteoarthritis Index (WOMAC) scores, both groups improved significantly but no significant difference was seen between the groups. Even if this study is based on small sample size and is not randomized, it indicates that PRP of 1 million plt $/ \mu \mathrm{L}$ could be sufficient in intra-articular injections due to the low capillary density in these sites. Further investigation is required to elucidate these aspects regarding PRP-treatment. If we assume as a working hypothesis that the PRP/media ratio of $10 \%(\mathrm{Vol} / \mathrm{Vol})$ is adequately imitating the condition in vivo and adjust the numbers accordingly, the optimal PRP concentration for cell proliferation the consequence of this ratio. The median of $1.55 \times 10^{6} \mathrm{plt} / \mu \mathrm{L}$ indicates that a PRP concentration of $1.5 \mathrm{plt} / \mu \mathrm{L}$ might function as a working hypothesis for further research in vitro or in vivo.

On the other hand, Cervelli et al. [4,44-50] reported the application of PRP in Plastic Surgery for the treatment of soft and bone tissue defects. In particular, they tested, for the first time in the literature, the in vitro impact of different PRP concentrations on AD-MSCs proliferation evaluating the related effects on in vivo tissue repair. Additionally, they evaluated the different percentages of fat graft maintenance enhanced with different PRP concentrations $[4,45,50]$. Regarding the in vitro test performed, they seeded $5000 \mathrm{AD}-\mathrm{MSC} / \mathrm{cm}^{2}$ in twenty-four-well plates incubating for twenty-four hours in DMEM containing 10\% FBS [4,49]. At the end of this time, finished after twenty-four hours, the medium has been substituted with DMEM $+10 \%$ FBS (control) and DMEM $+10 \%$ FBS $+5 \%$ PRP (study) $[4,49]$. After two, four, six and eight culture days, cells have been digested with $0.25 \%$ trypsin solution and then counted using a hemocytometer, with a trypan-blue exclusion [4]. The outcomes displayed a mean value of triplicate samples $[4,49]$. In detail, PRP produced a four-fold increase of AD-MSC number, at four and six days, when cells were at pre-confluency $(p<0.02)$ in morphological changes absence. After eight days, at confluency, there has been a three-fold increase of AD-MSCs number in PRP culture (study) versus control. Additionally, as mentioned above, they evaluated the related PRP dose-dependent impact in vivo, analyzing the wound healing in patients affected by the loss of substance [46,48], lower extremity ulcers [47] and the percentage of fat graft maintenance when used as lipofilling technique [45,50]. In detail, when the authors added $0.5 \mathrm{~mL}-0.4 \mathrm{~mL}$ of PRP per each $\mathrm{mL}$ of fat, they observed that $61.1 \%$ and $88.9 \%$ of chronic lower extremity ulcers displaying 
a $100 \%$ reepithelization after 7.1 and 9.7 -weeks, respectively, compared with $40 \%$ and $60 \%$ of the control group treated with HA. When $0.3 \mathrm{~mL}$ and $0.2 \mathrm{~mL}$ of PRP per each $\mathrm{mL}$ of the fat were added, $55.5 \%$ and $72.2 \%$ (for $0.3 \mathrm{~mL}$ ) and only $44.4 \%$ and $66.6 \%$ (for $0.2 \mathrm{~mL}$ ) respectively, of chronic lower extremity ulcers displayed the $100 \%$ re-epithelization during the same follow-up. They also observed in patients suffered by soft tissue defects treated with the combined use of fat grafting and PRP at a concentration of $0.5 \mathrm{~mL}$ or $0.4 \mathrm{~mL}$ per each $\mathrm{ml}$ of fat tissue, a $70 \%$ of fat graft maintenance one year later the treatment, observed only in $31 \%$ of the control group treated with the fat graft in absence of PRP addition; when they used $0.3 \mathrm{~mL}$ and $0.2 \mathrm{~mL}$ of PRP per each $\mathrm{mL}$ of fat tissue, they observed a $62 \%$ and $50 \%$ fat graft maintenance after one year. However, different cell types and tissue sites are factors that may up- or downregulate the optimal PRP concentration. Further research, in vitro and in vivo, is required to conclude this question.

\subsection{Suggested Guidelines for Further Research}

As shown, two main types of procedure have been utilized-The Fixed PRP Concentration Group leads to severe variation in nutrition availability in the culture. On the other side, The Fixed PRP Volume Group kept the nutrition level relatively constant throughout the experiment by limiting the variation within a smaller ratio. The latter group should be considered the most accurate for in vivo conditions. The exact number of cells per well and the volume of the well are factors that should be appreciated since an initial smaller number of cells $/ \mathrm{mL}$ would require less nutrition to proliferate compared to a high number.

Based on the above discussion, the following basic guidelines for further in vitro studies are recommended.

- The PRP/media ratio should be kept fixed throughout the experiment to minimize nutritional variations at different PRP concentrations.

- The PRP/media ratio should provide a sufficient nutrition supply to prevent cellular starvation, that is, PRP $\leq 10 \%$ (Vol/Vol). This implies that the initial PRP concentration should be high since an increase of concentration by increased volume is not recommended.

- The cell density (cells $/ \mathrm{mL}$ ) should be defined, that is, both the number of cells per well and nutrition volume should be clarified.

\subsection{Limitations}

This systematic review has several limitations that may pose a risk of possible biases:

Research in the last two decades strongly suggests that not only platelet concentration but also other biological qualities are crucial in regard to the effect of PRP [51]. Especially the role and number of white blood cells (WBCs) [52] and levels of fibrinogen/fibrin [53] have been highlighted as important co-elements. This review has not incorporated these aspects since several studies have not metrically clarified other biological properties of the PRP than platelet concentration.

Since the blood and the cultured cells came from different donors, the experiments in most of these studies were not autologous. Even if only PRP-lysate was used, graft versus host reactions are a possible bias. This point should especially be appreciated in the studies of Tavassoli-Hojjati et al. [31], who used PRP (not lysate), Mazzocca et al. [35] because of the high number of WBCs and Wang et al. [29] who used a diffusion chamber (DC). These important aspects fall outside the scope and frame of this review. Also, different activation method [26,31,36], $\mathrm{pH}$ condition [28] and the choice of anticoagulant [54] have been thematized in the literature as co-elements that can increase or decrease the effect of PRP and thus may pose risks of biases to this review.

One of the principal aspects revealed by the present systematic review has been the absence of a standardized protocol both for PRP preparation (kit vs. methods and procedures) and PRP injection (manual vs. mechanical and controlled) as well as a standardized evaluation method absence. The absence of standardization of these parameters making it more difficult to assess the effectiveness 
of PRP among the different investigations. Regarding the several and different procedures of PRP preparation, a lack of consensus regarding the choice of preparation method has been revealed, it influenced by centrifugation timing, g-force and RPM used, platelet concentration, blood volume gathered and amount of PRP injected. Treatment protocols also varied in the number of sessions, the time interval among procedures, the anticoagulant use and the follow-up period analyzed.

\section{Discussion}

The in vitro studies here reviewed state almost consistently that PRP stimulates the proliferation of the human cell. This observation is also the case regarding cell motility and exocytosis of several important regenerative extracellular ground substances, for example, collagen type I and III, HA and so forth. Regarding the optimal platelet concentration for cell proliferation, the studies diverge severely. The review reveals two main types of experimental techniques utilized-Group 1 used a fixed PRP concentration and altered the platelet concentration by adding the different volumes of this PRP-lysate to the culture. Group 2 used a fixed PRP-to-media ratio $(\mathrm{Vol} / \mathrm{Vol})$ throughout the experiment and altered the PRP concentration in the fixed PRP volume. An overall trait is seen-When the PRP concentration increases, the volume of culture media (nutrition) decreases and a lower optimal concentration for cell proliferation is observed. This is particularly prominent in group 1, The Fixed PRP Concentration Group, due to the diluting technique. We hypothesize that the techniques used by some groups led to adverse growth conditions and even cell starvation when high platelet concentrations were tested. Due to the constant nutrition supply and rapid diffusion of growth factors in all animals, the authors consider the studies that advocate a relatively high platelet concentration to best mimic the situation in vivo. Thus, the studies that advocate a low and moderate PRP concentration, for example, Graziani et al. [25], Giusti et al. [24] and Anitua et al. [21] are not supported. However, hyper-concentrations might also be inappropriate, especially in tissue types that are poorly vascularized. Based on the findings, the author suggests a platelet concentration of approx. $1.5 \times 10^{6} / \mu \mathrm{L}$ as a working hypothesis for further research in vitro and in vivo. Still, other concentrations might be beneficial depending on cell type and tissue site.

One of the problems most frequently raised by the scientific international audience is the level of consolidated evidence-based medicine (EBM) offered by PRP in the in vivo treatment of soft/bone tissue defects $[10,11,45,48,50]$, aesthetic defects [55], wound healing [46,47,56,57] and hair loss [5-7,58-61] compared versus FDA-approved and/or EMA/CAT and/or other institutions. The rationale of this problem is borne by the fact that many institutional guidelines of several nations are based on the EBM impact of a drug/procedure. For this reason, the authors feel the necessity to contribute consolidation of the EBM of PRP use via this systemic review of randomized/controlled/clinical trials (identified as EBM level 1a study), evaluating the in vitro impact of different PRP concentrations on cell proliferation, the related in vivo effect, reporting the most updated information compared with the last systemic reviews and adding an EBM 1a study to this topic.

\section{Conclusions}

This systematic review suggests a positive impact of PRP on tissue repair, as shown by in vivo, present a safe and effective procedure. Regarding the in vitro evaluation, the optimal PRP/media ratio was PRP $\leq 10 \%(\mathrm{Vol} / \mathrm{Vol})$ while the optimal platelet concentration since to start for effective PRP implication was $1.0-1.5 \times 10^{6} / \mu \mathrm{L}$.

Probably, the next future will be based exclusively on autologous and/or allogeneic regenerative based therapies and for this reason, it appears to be necessary to invite all the international audience to read the present work and related articles with the aim of promoting the publication of only EBM level $1-2$ studies.

Author Contributions: P.G. designed the studies, performed the procedures, analyzed the results, wrote the paper, wrote editing review, dealt with methodology and validation, performed the data analysis and conducted the study as leader; conceptualization, P.G. and S.G.; methodology, P.G. and S.G.; software, S.G.; validation, P.G. 
and S.G.; formal analysis, P.G.; investigation, P.G.; resources, P.G. and S.G.; data curation, P.G.; writing-original draft preparation, P.G.; writing-review and editing, P.G.; visualization, P.G.; supervision, P.G. and S.G.; project administration, P.G. and S.G.; funding acquisition, P.G. and S.G. All authors have read and agreed to the published version of the manuscript.

Funding: This research received no external funding.

Acknowledgments: This work was written totally by researcher Pietro Gentile. Independent mind, exclusively on the basis of scientific results selected and analyzed.

Conflicts of Interest: The authors declare no conflict of interest.

\section{Abbreviations}

$\begin{array}{ll}\text { PRP } & \text { Platelet-Rich Plasma } \\ \text { PPP } & \text { Platelet-poor plasma } \\ \text { A-PRP } & \text { Autologous-Non-activated Platelet-Rich Plasma } \\ \text { AA-PRP } & \text { Autologous-Activated Platelet-Rich-Plasma } \\ \text { GFs } & \text { Growth Factors } \\ \text { VEGF } & \text { Vascular endothelial Growth factors } \\ \text { PDGF } & \text { Platelet Derived Growth factors } \\ \text { IGF-1 } & \text { Insulin like Growth factor-1 } \\ \text { TGF- } B & \text { Transforming growth factor-beta } \\ \text { EGF } & \text { Epidermal growth factor } \\ \text { DPCs } & \text { Dermal papilla cells } \\ \text { EC } & \text { European Committee } \\ \text { CAT } & \text { Committee for Advanced treatments; } \\ \text { GMP } & \text { Good Manufacturing Practices } \\ \text { GCP } & \text { Good Clinical Practices } \\ \text { ECM } & \text { Extracellular matrix } \\ \text { SVFs } & \text { Stromal vascular Fraction Cells } \\ \text { AD-MSCs } & \text { Adipose-derived Mesenchymal Stem Cells } \\ \text { RPM } & \text { Right per minute } \\ \text { PRISMA-P } & \text { Preferred Reporting for Items for Systematic Reviews and Meta-Analyses-Protocols } \\ \text { CTGF } & \text { Connecting tissue growth factor } \\ \text { EBM } & \text { Evidence Based Medicine } \\ \text { MRI } & \text { Magnetic resonance imaging } \\ \text { CT } & \text { Computed Tomography } \\ \text { HA } & \text { Hyaluronic acid } \\ \text { OCEBM } & \text { Oxford Centre for Evidence-Based Medicine } \\ \text { WOMAC } & \text { Western Ontario and McMaster University's Osteoarthritis Index scores } \\ \text { WBCs } & \text { White blood cells } \\ \text { DMEM } & \text { Dulbecco's Modified Eagle Medium } \\ \text { FBS } & \text { Fetal Bovine serum } \\ \text { PLT } & \text { Platelets } \\ & \end{array}$

\section{References}

1. Gentile, P.; Calabrese, C.; De Angelis, B.; Dionisi, L.; Pizzicannella, J.; Kothari, A.; De Fazio, D.; Garcovich, S. Impact of the Different Preparation Methods to Obtain Autologous Non-Activated Platelet-Rich Plasma (A-PRP) and Activated Platelet-Rich Plasma (AA-PRP) in Plastic Surgery: Wound Healing and Hair Regrowth Evaluation. Int. J. Mol. Sci. 2020, 21, 431. [CrossRef]

2. Gentile, P.; Cole, J.P.; Cole, M.A.; Garcovich, S.; Bielli, A.; Scioli, M.G.; Orlandi, A.; Insalaco, C.; Cervelli, V. Evaluation of Not-Activated and Activated PRP in Hair Loss Treatment: Role of Growth Factor and Cytokine Concentrations Obtained by Different Collection Systems. Int. J. Mol. Sci. 2017, 18, 408. [CrossRef]

3. De Angelis, B.; D’Autilio, M.F.L.M.; Orlandi, F.; Pepe, G.; Garcovich, S.; Scioli, M.G.; Orlandi, A.; Cervelli, V.; Gentile, P. Wound Healing: In Vitro and In Vivo Evaluation of a Bio-Functionalized Scaffold Based on Hyaluronic Acid and Platelet-Rich Plasma in Chronic Ulcers. J. Clin. Med. 2019, 8, 1486. [CrossRef] 
4. Cervelli, V.; Gentile, P.; Scioli, M.G.; Grimaldi, M.; Casciani, C.U.; Spagnoli, L.G.; Orlandi, A. Application of Platelet-Rich Plasma in Plastic Surgery: Clinical andIn VitroEvaluation. Tissue Eng. Part C Methods 2009, 15, 625-634. [CrossRef] [PubMed]

5. Cervelli, V.; Garcovich, S.; Bielli, A.; Curcio, B.C.; Scioli, M.G.; Orlandi, A.; Gentile, P.; Cervelli, G. The Effect of Autologous Activated Platelet Rich Plasma (AA-PRP) Injection on Pattern Hair Loss: Clinical and Histomorphometric Evaluation. BioMed Res. Int. 2014, 2014, 760709. [CrossRef] [PubMed]

6. Gentile, P.; Garcovich, S.; Scioli, M.; Bielli, A.; Orlandi, A.; Cervelli, V. Mechanical and Controlled PRP Injections in Patients Affected by Androgenetic Alopecia. J. Vis. Exp. 2018, 27, 131. [CrossRef] [PubMed]

7. Cole, J.P.; Cole, M.A.; Insalaco, C.; Cervelli, V.; Gentile, P. Alopecia and platelet-derived therapies. Stem Cell Investig. 2017, 4, 88. [CrossRef]

8. Hausauer, A.K.; Humphrey, S. The Physician's Guide to Platelet-Rich Plasma in Dermatologic Surgery Part I. Dermatol. Surg. 2020, 46, 348-357. [CrossRef] [PubMed]

9. Hausauer, A.K.; Humphrey, S. The Physician's Guide to Platelet-Rich Plasma in Dermatologic Surgery Part II: Clinical Evidence. Dermatol. Surg. 2020, 46, 447-456. [CrossRef] [PubMed]

10. Gentile, P.; Bottini, D.J.; Spallone, D.; Curcio, B.C.; Cervelli, V. Application of Platelet-Rich Plasma in Maxillofacial Surgery. J. Craniofac. Surg. 2010, 21, 900-904. [CrossRef]

11. Metcalf, K.B.; Mandelbaum, B.R.; Mcllwraith, C.W. Application of Platelet-Rich Plasma to Disorders of the Knee Joint. Cartilage 2013, 4, 295-312. [CrossRef] [PubMed]

12. Blair, P.; Flaumenhaft, R. Platelet $\alpha$-granules: Basic biology and clinical correlates. Blood Rev. 2009, 23, 177-189. [CrossRef] [PubMed]

13. Neumüller, J.; Ellinger, A.; Wagner, T. Transmission Electron Microscopy of Platelets FROM Apheresis and Buffy-Coat-Derived Platelet Concentrates. Transm. Electron Microsc. Theory Appl. 2015, 255-284. [CrossRef]

14. Dhurat, R.; Sukesh, M. Principles and Methods of Preparation of Platelet-Rich Plasma: A Review and Author's Perspective. J. Cutan. Aesthet. Surg. 2014, 7, 189-197. [CrossRef] [PubMed]

15. Schücklenk, U.; Ashcroft, R. International Research Ethics. Bioethics 2000, 14, 158-172. [CrossRef] [PubMed]

16. Von Elm, E.; Altman, D.G.; Egger, M.; Pocock, S.J.; Gøtzsche, P.C.; Vandenbroucke, J.P. The Strengthening the Reporting of Observational Studies in Epidemiology (STROBE) statement: Guidelines for reporting observational studies. J. Clin. Epidemiol. 2008, 61, 344-349. [CrossRef]

17. Moher, D.; Liberati, A.; Tetzlaff, J.; Altman, D.G.; the PRISMA Group. Reprint—Preferred Reporting Items for Systematic Reviews and Meta-Analyses: The PRISMA Statement. Phys. Ther. 2009, 89, 873-880. [CrossRef]

18. Wells, G.A.; Shea, B.; O'Connell, D.; Peterson, J.; Welch, V.; Losos, M.; Tugwell, P. The Newcastle-Ottawa Scale for Assessing the Quality of Nonrandomised Studies in Meta-Analyses. 2014. Available online: http://www.ohri.ca/programs/clinical_epidemiology/oxford.asp (accessed on 19 June 2020).

19. Furukawa, T.A.; Barbui, C.; Cipriani, A.; Brambilla, P.; Watanabe, N. Imputing missing standard deviations in meta-analyses can provide accurate results. J. Clin. Epidemiol. 2006, 59, 7-10. [CrossRef]

20. Hozo, S.P.; Djulbegovic, B.; Hozo, I. Estimating the mean and variance from the median, range, and the size of a sample. BMC Med. Res. Methodol. 2005, 5, 13. [CrossRef]

21. Anitua, E.; Sánchez, M.; Zalduendo, M.M.; De La Fuente, M.; Prado, R.; Orive, G.; Andía, I. Fibroblastic response to treatment with different preparations rich in growth factors. Cell Prolif. 2009, 42, 162-170. [CrossRef]

22. Jo, C.H.; Kim, J.E.; Yoon, K.S.; Shin, S. Platelet-Rich Plasma Stimulates Cell Proliferation and Enhances Matrix Gene Expression and Synthesis in Tenocytes from Human Rotator Cuff Tendons with Degenerative Tears. Am. J. Sports Med. 2012, 40, 1035-1045. [CrossRef] [PubMed]

23. Wang, X.; Qiu, Y.; Triffitt, J.; Carr, A.; Xia, Z.; Sabokbar, A. Proliferation and differentiation of human tenocytes in response to platelet rich plasma: An in vitro and in vivo study. J. Orthop. Res. 2011, 30, 982-990. [CrossRef] [PubMed]

24. Giusti, I.; D’Ascenzo, S.; Mancò, A.; Di Stefano, G.; Di Francesco, M.; Rughetti, A.; Mas, A.D.; Properzi, G.; Calvisi, V.; Dolo, V. Platelet Concentration in Platelet-Rich Plasma Affects Tenocyte Behavior In Vitro. BioMed Res. Int. 2014, 2014, 630870. [CrossRef] [PubMed]

25. Graziani, F.; Ivanovski, S.; Cei, S.; Ducci, F.; Tonetti, M.; Gabriele, M. The in vitro effect of different PRP concentrations on osteoblasts and fibroblasts. Clin. Oral Implant. Res. 2006, 17, 212-219. [CrossRef] [PubMed]

26. Berger, D.R.; Centeno, C.J.; Steinmetz, N.J. Platelet lysates from aged donors promote human tenocyte proliferation and migration in a concentration-dependent manner. Bone Jt. Res. 2019, 8, 32-40. [CrossRef] 
27. Rughetti, A.; Giusti, I.; D’Ascenzo, S.; Leocata, P.; Carta, G.; Pavan, A.; Dell'Orso, L.; Dolo, V. Platelet gel-released supernatant modulates the angiogenic capability of human endothelial cells. Blood Transfus. 2008, 6, 12-17.

28. Mishra, A.; Tummala, P.; King, A.; Lee, B.; Kraus, M.; Tse, V.; Jacobs, C.R. Buffered Platelet-Rich Plasma Enhances Mesenchymal Stem Cell Proliferation and Chondrogenic Differentiation. Tissue Eng. Part C Methods 2009, 15, 431-435. [CrossRef]

29. Wang, K.; Li, Z.; Li, J.; Liao, W.; Qin, Y.; Zhang, N.; Huo, X.; Mao, N.; Zhu, H.; Ketao, W.; et al. Optimization of the Platelet-Rich Plasma Concentration for Mesenchymal Stem Cell Applications. Tissue Eng. Part A 2019, 25, 333-351. [CrossRef]

30. Hsu, C.-W.; Yuan, K.; Tseng, C.-C. The negative effect of platelet-rich plasma on the growth of human cells is associated with secreted thrombospondin-1. Oral Surg. Oral Med. Oral Pathol. Oral Radiol. Endodontol. 2009, 107, 185-192. [CrossRef]

31. Tavassoli-Hojjati, S.; Sattari, M.; Ghasemi, T.; Ahmadi, R.; Mashayekhi, A. Effect of platelet-rich plasma concentrations on the proliferation of periodontal cells: An in vitro study. Eur. J. Dent. 2016, 10, 469-474. [CrossRef]

32. Amable, P.R.; Teixeira, M.V.T.; Carias, R.B.V.; Granjeiro, J.M.; Borojevici, R. Mesenchymal Stromal Cell Proliferation, Gene Expression and Protein Production in Human Platelet-Rich Plasma-Supplemented Media. PLoS ONE 2014, 9, e104662. [CrossRef] [PubMed]

33. Haynesworth, S.E.; Kadiyala, S.; Liang, L.; Bruder, S.P. Mitogenic Stimulation of Human Mesenchymal Stem Cells by Platelet Releasate suggests a Mechanism for Enhancement of Bone Repair by Platelet Concentrate. In Proceedings of the 48th Annual Meeting of the Orthopaedic Research Society, Dallas, TX, USA, 10-13 February 2002.

34. Sadoghi, P.; Lohberger, B.; Aigner, B.; Kaltenegger, H.; Friesenbichler, J.; Wolf, M.; Sununu, T.; Leithner, A.; Vavken, P. Effect of platelet-rich plasma on the biologic activity of the human rotator-cuff fibroblasts: A controlled in vitro study. J. Orthop. Res. 2013, 31, 1249-1253. [CrossRef] [PubMed]

35. Mazzocca, A.D.; McCarthy, M.B.R.; Chowaniec, D.M.; Dugdale, E.M.; Hansen, D.; Cote, M.; Bradley, J.P.; Romeo, A.A.; Arciero, R.A.; Beitzel, K. The Positive Effects of Different Platelet-Rich Plasma Methods on Human Muscle, Bone, and Tendon Cells. Am. J. Sports Med. 2012, 40, 1742-1749. [CrossRef] [PubMed]

36. Jo, C.H.; Shin, J.S.; Shin, W.H.; Lee, S.Y.; Yoon, K.S.; Shin, S. Platelet-rich plasma for arthroscopic repair of medium to large rotator cuff tears: A randomized controlled trial. Am. J. Sports Med. 2015, 43, 2102-2110. [CrossRef]

37. Abate, M.; Silbernagel, K.G.; Siljeholm, C.; Di Iorio, A.; De Amicis, D.; Salini, V.; Werner, S.; Paganelli, R. Pathogenesis of tendinopathies: Inflammation or degeneration? Arthritis Res. Ther. 2009, 11, 235. [CrossRef]

38. Franchi, M.; Trirè, A.; Quaranta, M.; Orsini, E.; Ottani, V. Collagen Structure of Tendon Relates to Function. Sci. World J. 2007, 7, 404-420. [CrossRef]

39. Chen, B.; Sun, H.-H.; Wang, H.-G.; Kong, H.; Chen, F.-M.; Yu, Q. The effects of human platelet lysate on dental pulp stem cells derived from impacted human third molars. Biomaterials 2012, 33, 5023-5035. [CrossRef]

40. Palm, W.; Thompson, C.B. Nutrient acquisition strategies of mammalian cells. Nature 2017, 546, $234-242$. [CrossRef]

41. Heiden, M.G.V.; Cantley, L.C.; Thompson, C.B. Understanding the Warburg Effect: The Metabolic Requirements of Cell Proliferation. Science 2009, 324, 1029-1033. [CrossRef]

42. Kiritsy, C.P.; Lynch, S.E. Role of Growth Factors in Cutaneous Wound Healing: A Review. Crit. Rev. Oral Boil. Med. 1993, 4, 729-760. [CrossRef]

43. Dernek, B.; Kesiktas, F.N.; Duymus, T.M.; Aydin, T.; Isiksacan, N.; Diracoglu, D.; Aksoy, C. Effect of platelet concentration on clinical improvement in treatment of early stage-knee osteoarthritis with platelet-rich plasma concentrations. J. Phys. Ther. Sci. 2017, 29, 896-901. [CrossRef] [PubMed]

44. Cervelli, V.; Gentile, P. Use of Platelet Gel in Romberg Syndrome. Plast. Reconstr. Surg. 2009, 123, 22e-23e. [CrossRef] [PubMed]

45. Cervelli, V.; Palla, L.; Pascali, M.; De Angelis, B.; Curcio, B.C.; Gentile, P. Autologous Platelet-Rich Plasma Mixed with Purified Fat Graft in Aesthetic Plastic Surgery. Aesthet. Plast. Surg. 2009, 33, 716-721. [CrossRef] [PubMed] 
46. Cervelli, V.; De Angelis, B.; Lucarini, L.; Spallone, D.; Balzani, A.; Palla, L.; Gentile, P.; Cerulli, P. Tissue Regeneration in Loss of Substance on the Lower Limbs through Use of Platelet-Rich Plasma, Stem Cells from Adipose Tissue, and Hyaluronic Acid. Adv. Ski. Wound Care 2010, 23, 262-272. [CrossRef] [PubMed]

47. Cervelli, V.; Gentile, P.; De Angelis, B.; Calabrese, C.; Di Stefani, A.; Scioli, M.G.; Curcio, B.C.; Felici, M.; Orlandi, A. Application of enhanced stromal vascular fraction and fat grafting mixed with PRP in post-traumatic lower extremity ulcers. Stem Cell Res. 2011, 6, 103-111. [CrossRef] [PubMed]

48. Cervelli, V.; Lucarini, L.; Spallone, D.; Palla, L.; Colicchia, G.M.; Gentile, P.; De Angelis, B. Use of Platelet-Rich Plasma and Hyaluronic Acid in the Loss of Substance with Bone Exposure. Adv. Ski. Wound Care 2011, 24, 176-181. [CrossRef] [PubMed]

49. Cervelli, V.; Scioli, M.G.; Gentile, P.; Doldo, E.; Bonanno, E.; Spagnoli, L.G.; Orlandi, A. Platelet-Rich Plasma Greatly Potentiates Insulin-Induced Adipogenic Differentiation of Human Adipose-Derived Stem Cells Through a Serine/Threonine Kinase Akt-Dependent Mechanism and Promotes Clinical Fat Graft Maintenance. Stem Cells Transl. Med. 2012, 1, 206-220. [CrossRef]

50. Cervelli, V.; Bocchini, I.; Di Pasquali, C.; De Angelis, B.; Cervelli, G.; Curcio, C.B.; Orlandi, A.; Scioli, M.G.; Tati, E.; Delogu, P.; et al. P.R.L. Platelet Rich Lipotransfert: Our Experience and Current State of Art in the Combined Use of Fat and PRP. BioMed Res. Int. 2013, 2013, 434191. [CrossRef]

51. Dohan, D.M.; Choukroun, J.; Diss, A.; Dohan, S.L.; Dohan, A.; Mouhyi, J.; Gogly, B. Platelet-rich fibrin (PRF): A second-generation platelet concentrate. Part I: Technological concepts and evolution. Oral Surg. Oral Med. Oral Pathol. Oral Radiol. Endodontol. 2006, 101, e37-e44. [CrossRef]

52. Dohan, D.M.; Choukroun, J.; Diss, A.; Dohan, S.L.; Dohan, A.; Mouhyi, J.; Gogly, B. Platelet-rich fibrin (PRF): A second-generation platelet concentrate. Part III: Leucocyte activation: A new feature for platelet concentrates? Oral Surg. Oral Med. Oral Pathol. Oral Radiol. Endodontol. 2006, 101, e51-e55. [CrossRef]

53. Dohan, D.M.; Choukroun, J.; Diss, A.; Dohan, S.L.; Dohan, A.; Mouhyi, J.; Gogly, B. Platelet-rich fibrin (PRF): A second-generation platelet concentrate. Part II: Platelet-related biologic features. Oral Surg. Oral Med. Oral Pathol. Oral Radiol. Endodontol. 2006, 101, e45-e50. [CrossRef] [PubMed]

54. Amaral, R.J.F.C.D.; Da Silva, N.P.; Haddad, N.F.; Lopes, L.S.; Ferreira, F.D.; Filho, R.B.; Cappelletti, P.A.; De Mello, W.; Cordeiro-Spinetti, E.; Balduíno, A. Platelet-Rich Plasma Obtained with Different Anticoagulants and Their Effect on Platelet Numbers and Mesenchymal Stromal Cells Behavior In Vitro. Stem Cells Int. 2016, 2016, 1-11. [CrossRef] [PubMed]

55. Samadi, P.; Sheykhhasan, M.; Khoshinani, H.M. The Use of Platelet-Rich Plasma in Aesthetic and Regenerative Medicine: A Comprehensive Review. Aesthet. Plast. Surg. 2018, 43, 803-814. [CrossRef] [PubMed]

56. Smith, O.J.; Jell, G.; Mosahebi, A. The use of fat grafting and platelet-rich plasma for wound healing: A review of the current evidence. Int. Wound J. 2018, 16, 275-285. [CrossRef] [PubMed]

57. Han, J.; Gao, F.; Li, Y.; Ma, J.; Sun, W.; Shi, L.; Wu, X.; Li, T. The Use of Platelet-Rich Plasma for the Treatment of Osteonecrosis of the Femoral Head: A Systematic Review. BioMed Res. Int. 2020, 2020, 2642439. [CrossRef]

58. Gentile, P.; Garcovich, S. Systematic Review of Platelet-Rich Plasma Use in Androgenetic Alopecia Compared with Minoxidil ${ }^{\circledR}$, Finasteride ${ }^{\circledR}$, and Adult Stem Cell-Based Therapy. Int. J. Mol. Sci. 2020, $21,2702$. [CrossRef]

59. Gentile, P.; Garcovich, S. Autologous activated platelet-rich plasma (AA-PRP) and non-activated (A-PRP) in hair growth: A retrospective, blinded, randomized evaluation in androgenetic alopecia. Expert Opin. Boil. Ther. 2020, 20, 327-337. [CrossRef]

60. Gentile, P. Autologous Cellular Method Using Micrografts of Human Adipose Tissue Derived Follicle Stem Cells in Androgenic Alopecia. Int. J. Mol. Sci. 2019, 20, 3446. [CrossRef]

61. Alves, R.; Grimalt, R. Platelet-Rich Plasma and its Use for Cicatricial and Non-Cicatricial Alopecias: A Narrative Review. Dermatol. Ther. 2020, 10, 1-11. [CrossRef]

(C) 2020 by the authors. Licensee MDPI, Basel, Switzerland. This article is an open access article distributed under the terms and conditions of the Creative Commons Attribution (CC BY) license (http://creativecommons.org/licenses/by/4.0/). 